\title{
PERENCANAAN DAN PERANCANGAN SOLO EXHIBITION AND CONVENTION CENTER DI SURAKARTA Berpendekatan High Technology Architecture
}

\author{
Agus Bayu Purnomo \\ Program Studi Arsitektur, Fakultas Teknik, Universitas Tunas Pembangunan \\ Email: bayupurnomo017@gmail.com \\ Indro Sulistyanto \\ Dosen Program Studi Arsitektur, Fakultas Teknik, Universitas Tunas Pembangunan \\ Email: indrosulistyanto@yahoo.co.id \\ Rully \\ Dosen Program Studi Arsitektur, Fakultas Teknik, Universitas Tunas Pembangunan \\ Email: rullystmt@gmail.com
}

\begin{abstract}
Abstrak
Kota Surakarta atau yang lebih di kenal dengan Kota Solo sering mengadakan event - event besar berskala nasional maupun Internasional seperti PON 1948, Asean Para Games 2011, Kongres Nasional PSSI 2011, World Toilet Summit. Selain itu Kota Solo banyak mengadakan event - event setiap tahun seperti Pameran Teknologi, Solo Culinary Festival, Job Fair, Festival Budaya, Pemilihan Putra Putri Solo dan pertunjukan lainya yang berskala internasional seperti Solo Internasional Performing Art.

Tetapi kegiatan - kegiatan tersebut sering dilakukan terpisah karena kurangnya fasilitas untuk menampung kegiatan tersebut. Rata-rata bangunan Exhibition and Convention hanya ada di hotelhotel besar yang terpencar-pencar sehingga kurang memadai apabila diadakan sebuah acara Exhibition and Convention dalam skala besar atau internasional.

Melihat potensi kota dan keterbatasan fasilitas Exhibition and Convention Center yang tersedia di Kota Solo, maka diperlukan suatu fasilitas yang mampu mewadahi berbagai kegiatan Exhibition and Convention Center dengan segala fasilitas pendukungnya yang berskala internasional. Selain berdasarkan potensi kota, dipilih juga sebuah pendekatan yang mampu mendukung bangunan yaitu High Technology Architecture.
\end{abstract}

Kata Kunci : Solo, Exhibition, Convention

\begin{abstract}
The city of Surakarta or better known as the City of Solo often holds large national and international events such as PON 1948, Asean Para Games 2011, Kongres Nasional PSSI 2011, World Toilet Summit. In addition, Solo City holds many events every year such as the Technology Exhibition, Solo Culinary Festival, Job Fair, Cultural Festival, Election of the putra-putri Solo and other international-scale performances such as the Solo International Performing Art.

But these activities are often carried out separately because of the lack of facilities to accommodate these activities. The average Exhibition and Convention building is only available in large hotels that are scattered so that it is inadequate to hold a large-scale or international Exhibition and Convention event.

Seeing the city's potential and the limitations of the Exhibition and Convention Center facilities available in the city of Solo, a facility that is capable of accommodating various Exhibition and Convention Center activities with all its supporting facilities is on an international scale. In addition to the potential of the city, an approach that is capable of supporting buildings is High Technology Architecture.
\end{abstract}

Keyword: Solo, Exhibition, Convention 


\section{PENDAHULUAN}

Negara Indonesia saat ini sudah berkembang menjadi salah satu negara tujuan bisnis dan wisata yang memiliki peluang untuk mengembangkan potensi wisata MICE (Meeting, Incentive, Conference, and Exhibition). Hal itu dibuktikan dengan perolehan data dari Statistical Report on Visitor Arrivals to Indonesia 2012 menyimpulkan bahwa tujuan wisatawan mancanegara dalam kunjungan ke Indonesia yaitu 59\% untuk kepentingan liburan, 30\% untuk kepentingan Meeting, Incentive, Convention, and Exhibition (MICE) dan bisnis, dan sisa $11 \%$ untuk kepentingan lain (edukasi, formal, dll). Meeting, Incentive, Convention, and Exhibition (MICE) dalam industri pariwisata atau pameran, adalah suatu jenis kegiatan pariwisata di mana suatu kelompok besar, biasanya direncanakan dengan matang, berangkat bersama untuk suatu tujuan tertentu.

MICE (Meeting, Incentive, Conference,and Exhibition) dapat menjadi industri unggulan karena dapat menghasilkan devisa negara yang besar. Sektor ini juga dapat dijadikan indikator perkembangan ekonomi, sehingga sebagai sebuah negara, Indonesia membutuhkan infrastruktur yang baik serta SDM yang berkualitas. Keunggulan dikembangkannya industri MICE (Meeting, Incentive, Conference, and Exhibition) di Indonesia antara lain:
1. Menambah devisa negara

Pengembangan industri MICE bertujuan untuk meningkatkan citra Indonesia sebagai tujuan pariwisata yang aman, kerja sama antar daerah dan negara dalam memacu investasi sehingga meningkatkan devisa negara. Penambahan devisa negara juga berdampak terhadap jumlah wisatawan yang datang, lama tinggal, promosi, jumlah uang yang dibelanjakan, serta peningkatan infrastruktur.

2. Mendukung potensi daerah

Peran Pemerintah Daerah dalam mempromosikan wilayahnya sebagai destinasi wisata MICE perlu ditingkatkan. Pengadaan event MICE memberikan manfaat langsung terhadap potensi ekonomi daerah seperti akomodasi, convention center, usaha kuliner, cinderamata, hingga transportasi lokal.

3. Mendorong pertumbuhan ekonomi kreatif

Berbagai event MICE berskala internasional yang telah diselenggarakan di Indonesia diharapkan dapat menjadi media untuk mempromosikan produk-produk kreatif Indonesia. Berbagai jenis produk ekonomi kreatif yang dipamerkan akan mendorong tumbuhnya pelaku kreatif sehingga mampu mendukung ekonomi regional dan nasional. 
Pemerintah Indonesia sendiri telah menetapkan 10 destinasi MICE unggulan di Indonesia yakni Jakarta, Bali, Surabaya, Bandung, Yogyakarta, Medan, Padang, Batam, Manado, dan Makasar, meski telah kita ketahui Indonesia memiliki sepuluh Kota yang menjadi daerah wisata MICE, namun jika dilakukan pengkajian lebih mendalam sebenarnya Indonesia memiliki banyak wilayah yang berpotensi sebagai daerah wisata MICE salah satunya adalah Kota Surakarta.

Walaupun Kota Surakarta atau yang lebih di kenal dengan sebutan Kota Solo tidak termasuk dalam sepuluh wilayah daerah wisata MICE, namun Kota Solo memiliki potensi yang cukup kompetitif untuk masuk kedalam zona industri ini hal ini terbukti dengan sering dipilihnya Kota Solo sebagai tempat penyelenggaraan event berskala nasional maupun internasional.

Tetapi sayangnya kegiatan - kegiatan tersebut sering dilakukan terpisah karena kurangnya fasilitas untuk menampung kegiatan tersebut dalam satu bangunan, padahal kegiatan tersebut saling berhubungan. Rata-rata bangunan Exhibition and Convention hanya ada di hotel-hotel besar yang seringnya terpencar-pencar sehingga kurang memadai apabila diadakan sebuah acara Exhibition and Convention dalam skala besar atau internasional. Kota Solo mempunyai potensi untuk dibangunnya sebuah Solo Exhibition and Convention Center. Kebutuhan akan sebuah wadah yang mampu menampung berbagai kegiatan Exhibition and Convention di Solo yang dirasakan masih kurang. Selain itu posisi kota Solo yang berada diantara Semarang dan Yogyakarta yang merupakan pusat kegiatan perekonomian di Jawa Tengah turut mempercepat pertumbuhan perekonomian di Kota Solo termasuk peningkatan kebutuhan akan tempat promosi dan pemasaran produk-produk dagang khususnya produk Solo.

Melihat potensi kota dan keterbatasan fasilitas Exhibition and Convention Center yang tersedia di kota Solo, maka diperlukan suatu fasilitas yang mampu mewadahi berbagai kegiatan Exhibition and Convention Center dengan segala fasilitas pendukungnya yang berskala internasional. Selain berdasarkan potensi kota, dipilih juga sebuah pendekatan yang mampu mendukung bangunan yaitu High Technology Architecture yang cocok untuk bangunan yang mempunyai bentang lebar dan juga saling mendukung antara fisik bangunan dengan kegiatan yang diwadahinya.

\section{PERMASALAHAN}

Bagaimana merencanakan dan merancang Solo Exhibition and Convention Center yang mampu mewadahi berbagai kegiatan convention, exhibition, pertunjukan serta promosi yang berskala internasional yang berlandaskan prinsip High Technology Architecture pada bangunan.

\section{METODE PEMBAHASAN}

Metode pembahasan yang digunakan yaitu deskriptif kualitatif analisis dan sintesis 
yaitu dengan menguraikan wadah kegiatan dimaksud secara tidak terukur (kualitatif), relevan (analitik) dengan menguraikan kedalam unsur, elemen dan komponen untuk masing-masing dikaji dan dicari keterkaitannya (analisis), yang kemudian dipadukan kembali sebagai satu kesatuan (sintesis) dalam desain.

\section{LANDASAN TEORI}

\section{1) Pengertian Exhibition}

Pengertian Exhibition menurut Oxford Dictionary adalah pertunjukan atau pameran yang dilakukan secara umum, atau kegiatan memamerkan.

\section{2) Pengertian Convention}

Menurut Fred Lawson (1981). Convention adalah pertemuan oleh orang - orang untuk sebuah tujuan atau untuk bertukar pikiran, berupa pendapat dan informasi dari sesuatu perhatian atau permasalahan bersama dari sebuah kelompok.

\section{3) Pengertian Center}

Center menurut Oxford Dictionary diartikan sebagai titik tengah dari tempat atau sekelompok bangunan sehingga membentuk poin inti dari sebuah jalan atau area, pusat konsentrasi atau titik dari penyebaran

\section{4) Kesimpulan Exhibition And}

\section{Convention Center}

Exhibition And Convention Center adalah suatu tempat atau wadah yang didalamnya terdapat berbagai kegiatan khusus atau sebagai pusat kegiatan pertemuan dan juga tempat pameran guna mengakomodir para pelaku kegiatan.

\section{5) Pengertian High technology Architecture}

Menurut Colin Davies (1988), pengertian high technology dalam bidang arsitektur berbeda dengan high technology dalam bidang industri. Dalam bidang industri, high technology diartikan sebagai teknologi canggih, seperti: perangkat elektronik, robot, komputer, kendaraan bermesin dan lain sebagainya. Sedangkan dalam arsitektur, high technology diartikan sebagai suatu aliran atau gaya yang bermuara pada ide gerakan arsitektur yang mencoba mengikuti dan memanfaatkan perkembangan teknologi bangunan sehingga arsitektur sejalan dan saling terkait dengan perkembangan teknologi.

Sedangkan Menurut Charles Jenks (1990), elemen struktur dan servis pada suatu bangunan high technology hampir selalu diperlihatkan di eksteriornya sebagai ornamen dan sclupture. Bangunan high technology juga diperlihatkan dengan menggunakan kaca buram maupun transparan, ducting yang selalu tumpang tindih, penggunaan warna pada tangga, ekskalator dan lift dengan warna-warna cerah yang bertujuan membedakan fungsi masing-masing elemen struktur dan servis. 


\section{HASIL DAN PEMBAHASAN}

1) Lokasi Tapak

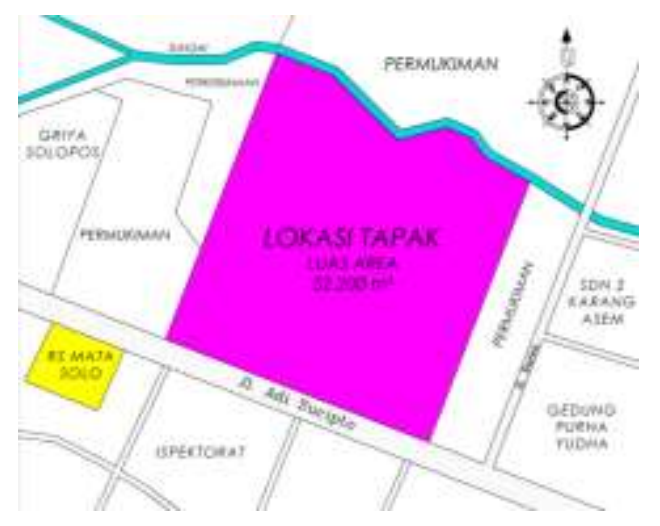

Gambar 1. Lokasi Tapak

Tapak merupakan daerah untuk kegiatan pariwisata, olah raga dan industri kreatif, dengan kondisi sebagai berikut.

a) Merupakan Sub pusat pelayanan kota II (SPK II) di Kota Surakarta

b) Kontur tanah relatif datar, dengan luas $52.200 \mathrm{~m}^{2}$

c) Terletak di Jln. Adi Sucipto, Karangasem, Laweyan, Kota Surakarta

d) Lokasi sekitar terdapat Hotel Alana, dan dekat Bandara Adi Sumarmo.

e) Batas-batas tapak

- Utara : Sungai.

- Timur : Permukiman.

- Selatan : Jl. Adi Sucipto.

- Barat : Permukiman.

\section{2) Pengolahan Tapak}

a) Pencapaian Makro

Alternatif Pencapaian :

1) Dari Kota Semarang, Kab. Boyolali Dan Yogyakarta melalui
- Jl. Ahmad Yani $\rightarrow$ Jl. DR Soeharso $\rightarrow$ Jl. Adi Sucipto

- Tol Solo-Kertosono

2) Dari Bandara Adi Sumarmo melalui

- Jl. Adi Sucipto

3) Dari Kab. Wonogiri Dan Kab. Sukoharjo melalui

- J1. Solo-Wonogiri $\rightarrow$ J1. Radjiman $\rightarrow$ J1. Dr Wahidin $\rightarrow$ Jl. Slamet riyadi $\rightarrow$ Jl. DR Soeharso $\rightarrow$ Jl. Adi Sucipto

4) Dari Sragen dan Jawa Timur melalui

- J1. Solo-Sragen $\rightarrow$ Jl. Kolonel Sutarto $\rightarrow$ Jl. A.Yani $\rightarrow$ Jl. Adi Sucipto

- Tol Solo-Kertosono $\rightarrow$ Gerbang Tol Solo $\rightarrow$ Jl Adi Sumarmo $\rightarrow$ Jl Adi Sucipto

\section{b) Pencapaian Mikro}

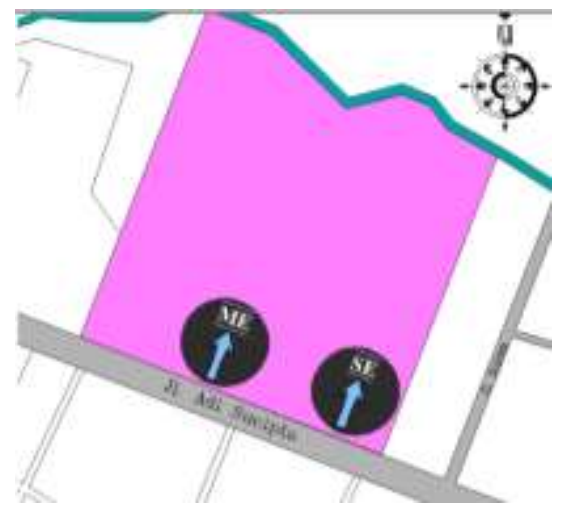

Gambar 2. Pencapaian 


\section{c) Orientasi}

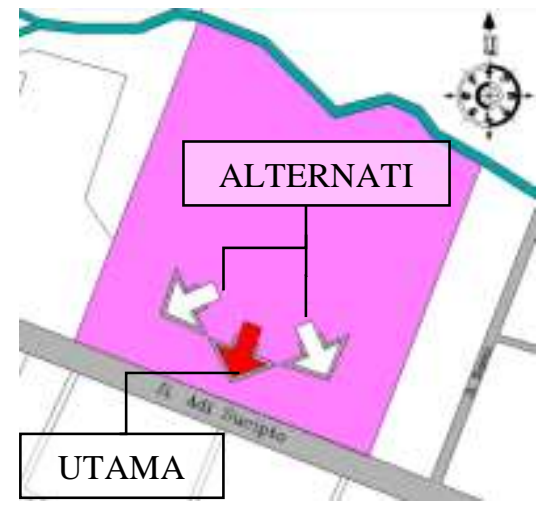

Gambar 3. Orientasi

\section{d) Kebisingan}

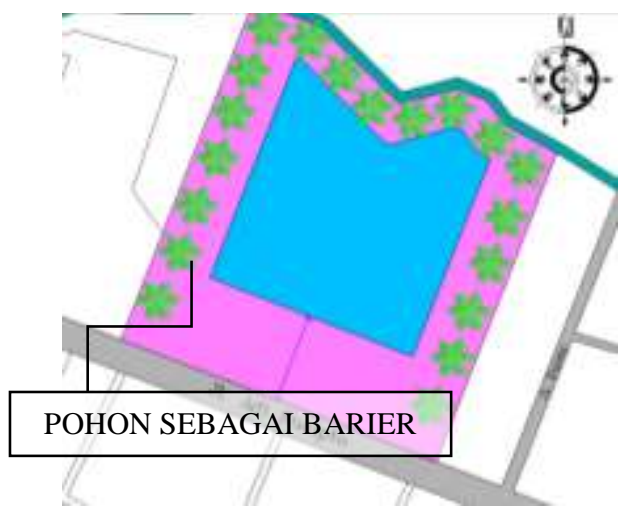

Gambar 4. Kebisingan

e) Titik Tangkap

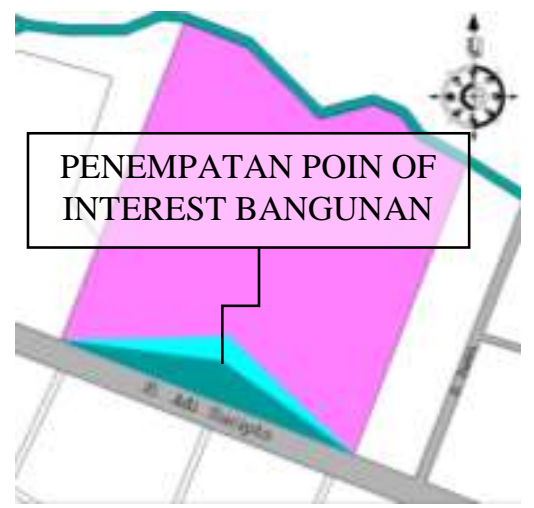

Gambar 5. Titik Tangkap

\section{3) Besaran Ruang}

\begin{tabular}{|c|l|l|c|}
\hline No & \multicolumn{2}{|c|}{ Kelompok Kegiatan } & Luas Lantai \\
\hline \multirow{2}{*}{1} & $\begin{array}{l}\text { Kelompok } \\
\text { kegiatan } \\
\text { utama }\end{array}$ & Exhibition & $\mathbf{1 2 . 1 6 5 , 5 1} \mathrm{m}^{2}$ \\
\cline { 2 - 4 } 2 & \multicolumn{2}{|l|}{ Kelompok kegiation } & $\mathbf{1 2 . 6 7 1 , 0 5} \mathrm{m}^{2}$ \\
\hline
\end{tabular}

\begin{tabular}{|c|l|c|}
\hline & Penunjang & \\
\hline 3 & $\begin{array}{l}\text { Kelompok kegiatan } \\
\text { Pengelola }\end{array}$ & $\mathbf{2 9 6 , 8 8} \mathrm{m}^{2}$ \\
\hline 4 & $\begin{array}{l}\text { Kelompok kegiatan } \\
\text { Servise }\end{array}$ & $\mathbf{1 1 0 0 , 3 9 \mathrm { m } ^ { 2 }}$ \\
\hline 5 & Parkir indoor & $\mathbf{3 4 6 2 7 , 5} \mathrm{m}^{2}$ \\
\hline \multicolumn{2}{|c|}{ Total Luas Lantai } & $\mathbf{6 3 . 2 4 4 , 4 5} \mathbf{~ m}^{\mathbf{2}}$ \\
\hline \multicolumn{2}{|c|}{ Tabel 1. Besaran Ruangan } \\
\hline
\end{tabular}

\section{Perhitungan :}

1) Luas Tapak

$$
=52.200 \mathrm{~m}^{2}
$$

2) Total luas lantai $=63.244,45 \mathrm{~m}^{2}$

3) $\mathrm{KDB}$

$$
=40 \%
$$

4) Perhitungan

$$
\begin{aligned}
\mathrm{KDB} / \mathrm{BC} & =40 \% \times \text { luas tapak } \\
& =40 \% \times 52.200 \\
& =20880 \\
\text { Open Space } & =\text { luas tapak }-\mathrm{KDB} \\
& =52.200-20880 \\
& =31320
\end{aligned}
$$

Ketinggian

Lantai $=$ Total luas lantai $: \mathrm{KDB}$

$=63.244,45: 20880$

$=3,1: 4$ lantai

\section{4) Ungkapan Fisik Bangunan}

\section{a) Bentuk Dasar Massa}

Bentuk massa bangunan tidak terlepas dari bentuk ruang sebagai tempat kegiatan, maka dari itu dapat dihasilkan bentuk massa bangunan dengan dasar kriteria :

1) Kesesuaian dengan bentuk site 
2) Bentuk dari karakter dari sifat ruang serta efektifitas pengguna ruang

3) Fleksibel terhadap fungsi bangunan

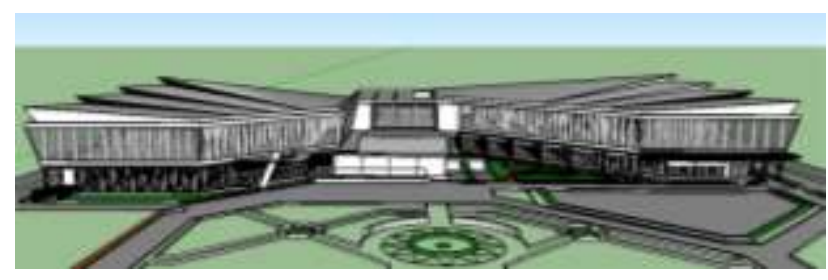

Gambar 6. Bentuk Massa Bangunan

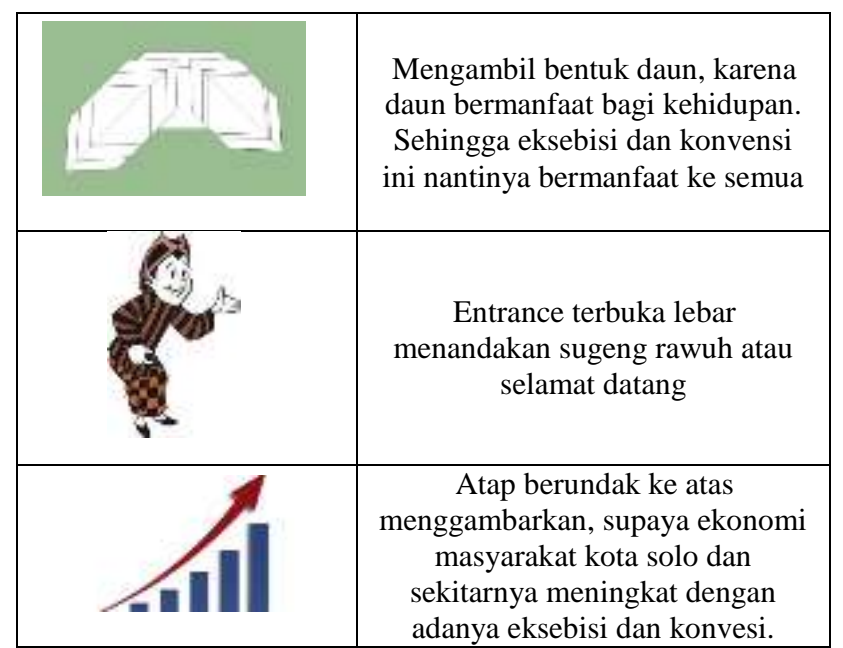

b) Penampilan Bangunan

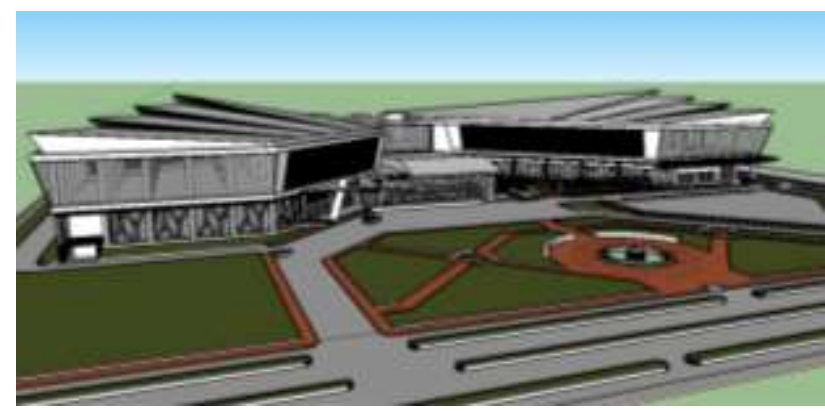

Gambar 7. Penampilan Bangunan

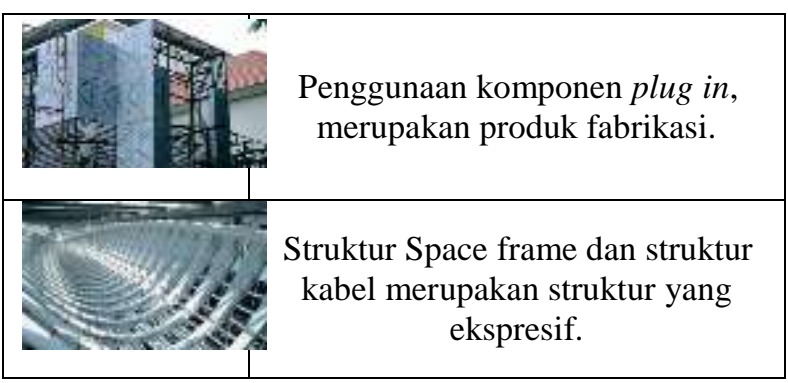

\begin{tabular}{|c|c|}
\hline & $\begin{array}{l}\text { Transparancy : Bentuk transparan } \\
\text { untuk mengoptimalkan cahaya } \\
\text { matahari, dan mengekpose kegiatan } \\
\text { yang ada di dalam bangunan. }\end{array}$ \\
\hline & $\begin{array}{c}\text { Optimistic Confidence in } \\
\text { Scientific Culture } \text { : dengan } \\
\text { penerapan kantilever, atap yang } \\
\text { sedikit dimainkan memberikan } \\
\text { kesan moderen dan memanfaatkan } \\
\text { teknologi struktur bangunan yang } \\
\text { dapat bertahan cukup lama. }\end{array}$ \\
\hline & $\begin{array}{c}\text { Celebration of processe } \text { : dengan } \\
\text { ide bentuk pada gambar di atas, } \\
\text { kemampuan struktur dari bangunan } \\
\text { tersebut terlihat jelas }\end{array}$ \\
\hline & $\begin{array}{l}\text { Penggunaan vegetasi vertical } \\
\text { garden sebagai bagian dari } \\
\text { penyatuan dengan system alam. }\end{array}$ \\
\hline 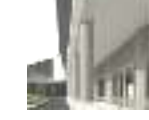 & $\begin{array}{l}\text { Menggunakan warna-warna cerah } \\
\text { atau monokrom }\end{array}$ \\
\hline
\end{tabular}

c) Struktur

\section{Sub Struktur}

Tiang Pancang

Mendukung bangunan

berlantai banyak, cocok untuk tanah yang cukup keras, penggalian tanah untuk pondasi cukup dalam.

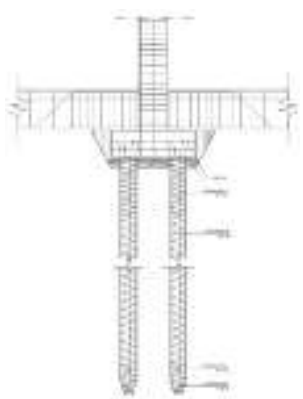

Gambar 8. Pondasi Tiang Pancang

Alternatif pondasi yang digunakan adalah pondasi tiang pancang yang memiliki

karakteristik sesuai dengan jenis tanah area site yang cukup

keras. Selain itu tipologi 
bangunan High Technology

Architecture banyak

menggunakan material-material seperti baja, dan besi, sehingga

beban bangunan pada tanah akan sangat berat.

\section{Super Struktur}

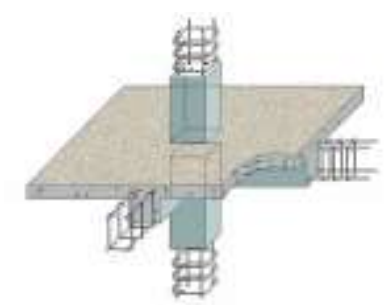

Gambar 9. Super Struktur

Super Struktur merupakan struktur tubuh bangunan yang berfungsi memikul beban atap di atasnya dan sebagai pembatas visual suatu bangunan seperti : dinding, kolom, dan balok.

\section{Upper Struktur (Struktur}

\section{Atap)}

\section{Space frame.}

Bentangan relatif besar,

kemungkinan variasi bentuk atap lebih luas.

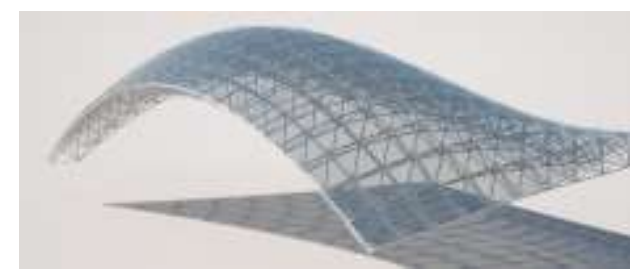

Gambar 10. Space frame

Mengingat bangunan Exhibition and

Convention Center ini memiliki

variasi bentangan dan bentuk yang beragam maka Upper Struktur yang digunakan adalah Struktur Space

frame dan struktur rangka, struktur

kabel sebagai alternative

\section{5) Gambar Bangunan}

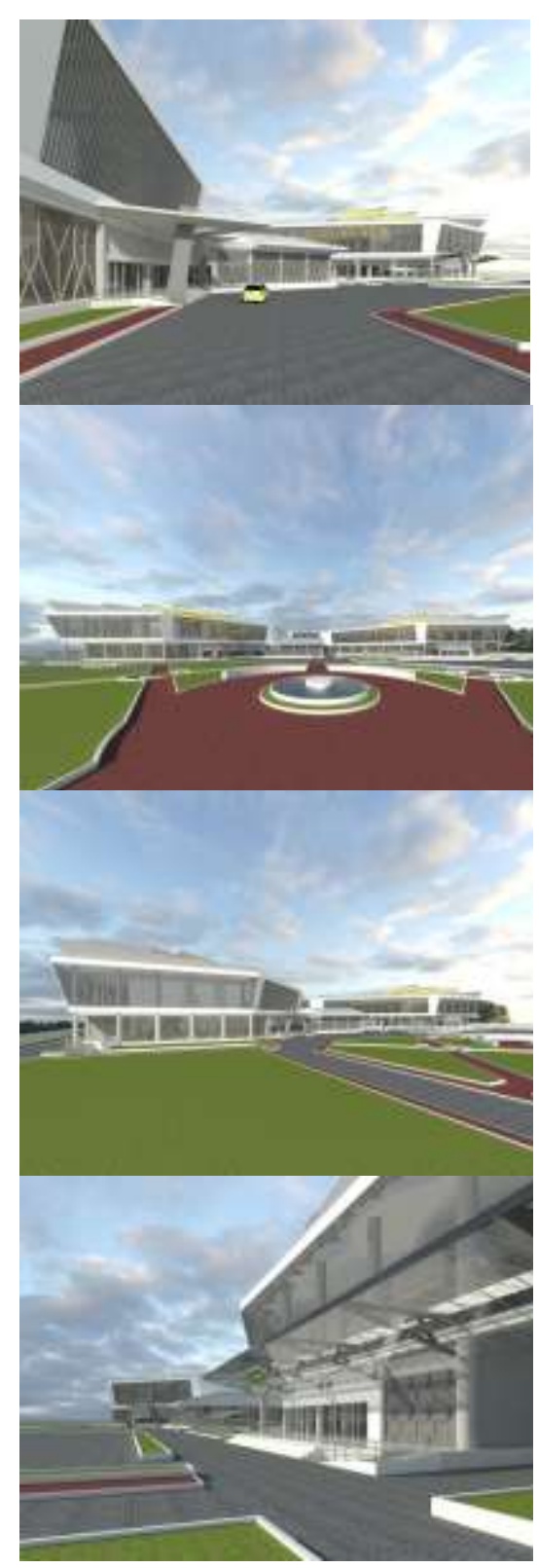

Gambar 11. Prespektif

\section{KESIMPULAN}

Solo Exhibition and Convention Center diharapkan mampu mewadahi dan memfasilitasi berbagai kegiatan convention, exhibition, pertunjukan serta promosi yang berskala internasional. 
Selain itu, dengan adanya bangunan

Solo Exhibition and Convention Center

tersebut mampu memberikan dampak

posistif terhadap perekonomian

masyarakat Solo dan sekitarnya. Acara-

acara yang diselenggarakan tentu akan

mendatangkan banyak pengunjung dari

berbagai daerah, sehingga secara tidak

langsung masyarakat dapat lahan

pekerjaan, seperti menjual berbagai

cinderamata khas daerah, makan-

makanan khas daerah, dan lain - lain.

\section{UCAPAN TERIMA KASIH}

1. Kepada Bapak Ir. Indro Sulistyanto, MT. selaku Dosen Pembimbing Utama

2. Kepada Bapak Ir. Rully, ST, MT., selaku Dosen Pembimbing Pembantu

3. Kepada Ibu Ir. Eny Krisnawati, M.Si., selaku Ketua Dekan Fakultas Teknik Universitas Tunas Pembangunan.

4. Kepada Bapak A. Bamban Yuuwono ST., MT, selaku Ketua Program studi Arsitektur Fakultas Teknik Universitas Tunas Pembangunan Surakarta

5. Kepada Kedua Orang Tua dan Seluruh anggota keluarga kakak - kakak saya

6. Kepada seluruh rekan angkatan 2015 khususnya teman - teman yang rela meluangkan waktu untuk membantu pengerjaan tahap desain

7. Semua pihak yang tidak dapat disebutkan satu per satu, yang telah ikut membantu secara langsung maupun tidak langsung

\section{DAFTAR PUSTAKA}

Lawson, Fred. 1981. Conference, Convention and Exhibition Facilities. London: The Architectural Press

Cyril M Harris, Dictionary of Architecture and Construction, McGraw-Hill, Inc, United Stated of America, 1975

Kebijakan Menteri Pariwisata, Pos, dan Telekomunikasi No. KM/108/HM 703/MPPT-91 tentang Usaha Jasa Konvensi, Perjalanan Insentif dan Pameran

Oxford University. 1991.Oxford Advanced Learner's Dictionary. Oxford University. Inggris

Jencks, Charlse. 1988. The battle of hightech: great buildings with great faults. Architectural Design vol. 58 no. 11. hlm. 18-39

Davies, C. 1988. High-Tech Architecture. London: Thames and Hudson 